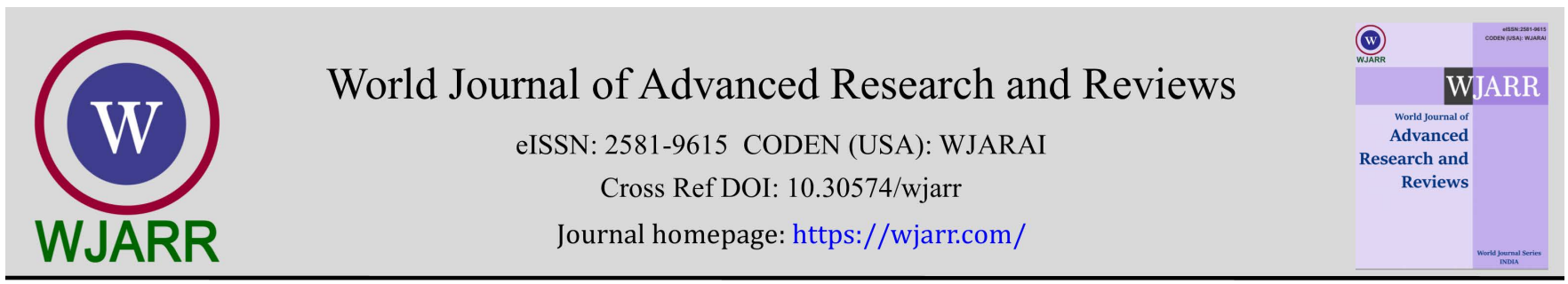

(RESEARCH ARTicle)

\title{
On the image promotion on social media by polytechnic students in Nigeria
}

\author{
Taiwo Stephen Fayose, Lanre Adebara * and Folashade Adeola Bolarinwa \\ Department of Mathematics and Statistics, The Federal Polytechnic, Ado Ekiti, Ekiti State, Nigeria.
}

World Journal of Advanced Research and Reviews, 2021, 09(01), 188-197

Publication history: Received on 04 January 2021; revised on 11 January 2021; accepted on 13 January 2021

Article DOI: https://doi.org/10.30574/wjarr.2021.9.1.0009

\begin{abstract}
The research examined the reasons polytechnic students join social media such as Instagram and what they intend to learn from celebrities on Instagram in order to have their ideal body image for self-esteem. The study identified different measures polytechnic students used to achieve desired body image and the level of psychological effect Instagram posts have on their body image. The analysis is based on the findings of a questionnaire survey carried out in two higher institutions in Nigeria $(\mathrm{N}=600)$. The results revealed Nigerian students are highly conscious of their body image (91.2\%), they employed different measures to achieve their desired body image, the rate at which Nigerian students patronized products advertised on Instagram to acquire ideal beauty standard is relatively high (61.5\%) and finally, level of psychological effect of Instagram posts on body image is approximately high (88\%).
\end{abstract}

Keywords: Instagram posts; Body Image; Purposive Sampling Technique; Likert Scale; Chi Square Test

\section{Introduction}

Social Networking Sites especially social networking sites such as Facebook, Twitter, Tik Tok and Instagram have become a huge part of most youths' lives in recent years (Agliata and Tantleff-Dunn, 2004; Yayli et al. 2014). Originally, they are meant for interaction and building connections with new friends officially and otherwise (Robertson, 2014). Anyone can become a member of any of these sites through registration including adding photos. Researchers such as (Boyd and Ellison, 2007; Grabe et al. 2008) analyzed social networking sites as phenomenon, presentation of the self on social networking sites (Hochman and Schwartz, 2012; Salomon, 2013; Bakhshi et al. 2013).

Olofin et al. (2020) defined Instagram as an image-based social networking site that is famous among Nigerian students most especially those in tertiary institutions. Instagram allows users to take photos, post these photos to their personalized pages, and further disseminate the content by linking through other social media accounts like Facebook and Twitter. The popularity of Instagram is often linked with the rise of a new social phenomenon known as selfies (i.e., self-portrait style photographs) (Smith, 2014). The selfie phenomenon has gained a great deal of public attention, with selfie being named the 2013 word of the year by Oxford Dictionaries (Bergstrom and Backman, 2013; Smith, 2014).

Abbott et al. (2013) and Wagner et al. (2016) opined that a selfie's focus on physical form might come with unintended associations for users who possess different levels of confidence and comfort with their bodies. The present study seeks to examine how Instagram influences body image among tertiary institutions students in Nigeria while seeking to determine whether the frequency of selfies taken and posted to Instagram are related to users' actual body size and sense of body dissatisfaction. This knowledge will help identify the psychological effects that Instagram posts on body image has on Nigerian students.

${ }^{*}$ Corresponding author: Lanre Adebara; Phone no: +2347030538802; email: adebara_la@fedpolyado.edu.ng Department of Mathematics and Statistics, The Federal Polytechnic, Ado Ekiti, Ekiti State, Nigeria. 
Yamamiya et al. (2005) and Adamic and Adar (2005) affirmed that young females struggle with perceptions of the ideal body image and this affects them with their self-esteem and educational development. Social media contributes greatly to this distortion, alongside peers, family and society (Bakhshi et al., 2013).

However, in the Nigerian society today, young females especially, are likely pressured to conform to change their appearance to certain beauty standards seen on different social networking sites (Olofin et al., 2020). This is because they aim at having the body shape, size or complexion of celebrities or other people which they have seen on social media (Barlett et al., 2013). The media has a way of prioritizing certain body image to be more attractive than the others e.g extreme thinness, big breasts and tiny waist for women and V-shaped muscled body for men etc (Barlett et al., 2013; Chante et al., 2014). Therefore, female undergraduates are on a daily basis confronted with the traditional and stereotypical ideals of beauty standards and regarding that it may be the first time they are allowed to make certain choices on their own, they are often faced with mixed messages regarding their value as students and the need to always look attractive (Olofin et al., 2020).

The pursuit to conform to distorted beauty ideals and body image as Nigerian students is related to different problems which could include lack of self-confidence, low self-esteem among others.

Li and Agarwal, (2014); Campbell, (2017) and Constine, (2017) argued that millions of people are daily living with a dreadful feeling about how they look and that means they are not satisfied with their body image, which inevitably leads to low self-esteem.

\section{Material and methods}

The research design employed in this study was Survey Research Design. The Survey Research Design allows for easy administration of questionnaires to users of Instagram among the respondents at Federal Polytechnic, Ado Ekiti and Yaba College of Technology, Lagos to arrive at a reasonable result on the influence of Instagram on the body image of students of the two selected Polytechnics for this research. The population of the study comprised Instagram users among students of both institutions. The two polytechnics have combined population of about 60,000 students. The sample size for the study was 600 drawn from all the Schools from the two institutions. Purposive sampling technique was employed to select 75 students each from the eight colleges/schools in both institutions.

Questionnaire was used as the measuring instrument. The questionnaire was grouped into five sections. Demographics, Consciousness of Body Image, Measures Taken to Achieve Desired Body Image, Patronized Body Image Products Advertised on Instagram, Psychological Effects that Instagram Posts have on Body Image and Demographics Information. Section A contains five (5) items on demographic information such as Gender, Age, College/School, Institution and Instagram account. The next section contains 10 items about the consciousness of the body image of young females. A Four step Likert Scale questionnaire was used to extract crucial information from Respondents. Responses ranged from Strongly Agreed (SA) Agree (A) Disagree (D) Strongly Disagree (SD). The next subsection contains 10 items about measures taken to achieve desired body image using the open ended response scale of either "Yes" or , "No" while the next subsection contains 10 items about the patronage of body image products advertised on Instagram using the scale Regularly, Rarely and Never. The next sub-section also contains 10 items about the psychological effects that Instagram posts have on body image. The response scale is Highly (H) Minimal (M) Low (L). The instrument used was validated through a peered review by colleagues in both institutions.

Data collected through the questionnaire was collated, arranged, coded and computed using the Computer Statistical Package for Social Sciences (SPSS) version 22. Descriptive and inferential statistics were used to analyze the data in accordance to the research questions. The methods used in the study are descriptive statistics tools such as Bar chart, Pie Chart and Chi-square test.

\section{Results and discussion}

Table 1 Distribution of Respondents by Gender

\begin{tabular}{|l|l|l|}
\hline Gender & Frequency & Percentage \\
\hline Male & 34 & 5.7 \\
\hline Female & 281 & 94.3 \\
\hline Total & 600 & $100 \%$ \\
\hline
\end{tabular}


Table 1 shows the distribution of respondents by gender. The result reveals that $5.7 \%$ of the respondents are male students while $94.3 \%$ are female students in the two Polytechnics selected. Thus, majority of the respondents are female

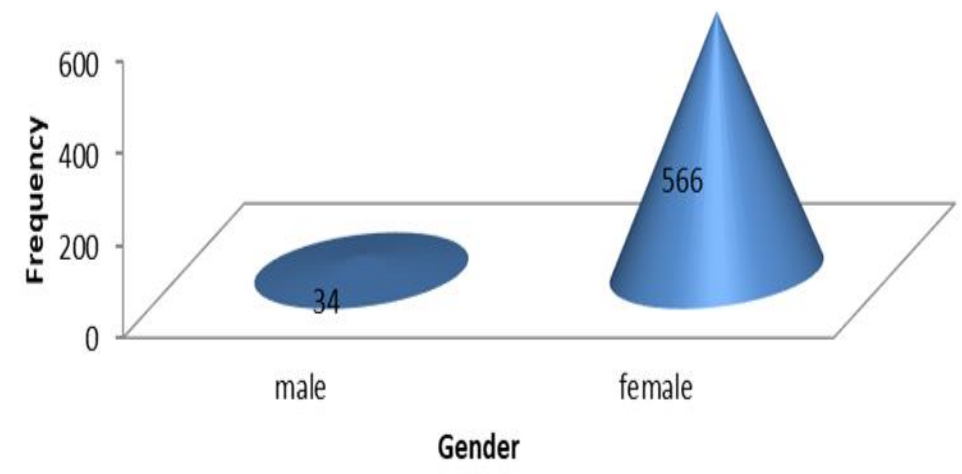

Figure 1Distribution of respondents by gender in the two Polytechnics

Table 2Age Distribution of Respondents

\begin{tabular}{|l|c|c|}
\hline Age & Frequency & Percentage \\
\hline 15yrs \& below & 7 & 1.2 \\
16-20yrs & 175 & 29.2 \\
$21-25 y r s$ & 322 & 53.7 \\
$26-30 y r s$ & 77 & 12.8 \\
$31-35 y r s$ & 19 & 3.2 \\
\hline Total & 600 & $100 \%$ \\
\hline
\end{tabular}

Table 2 shows the age distribution of the respondents. The result reveals that $53.7 \%$ of the respondents are in the age group $21-25 y r s, 29.2 \%$ are in the age group 16-20yrs and finally, $12.8 \%$ are in the age group 26-30yrs. Majority of the respondents are in the age group 21 - 25yrs which is the mode.

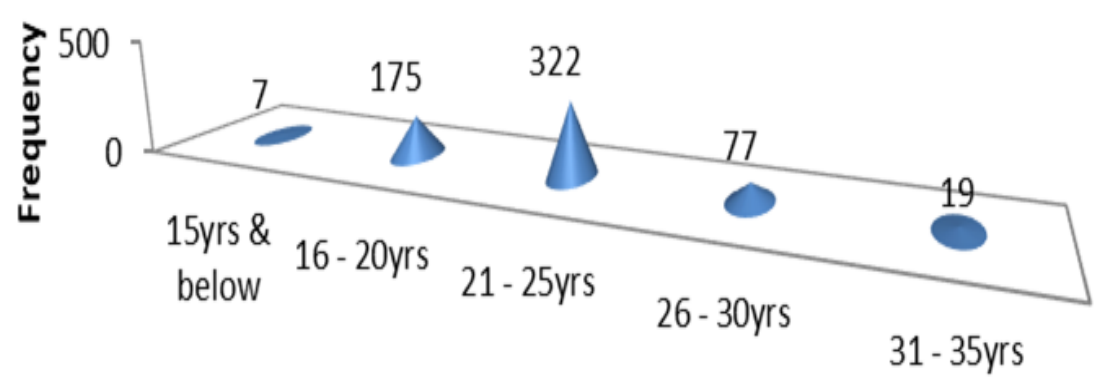

\section{Age Group}

Figure 2 Age distribution of the respondents 


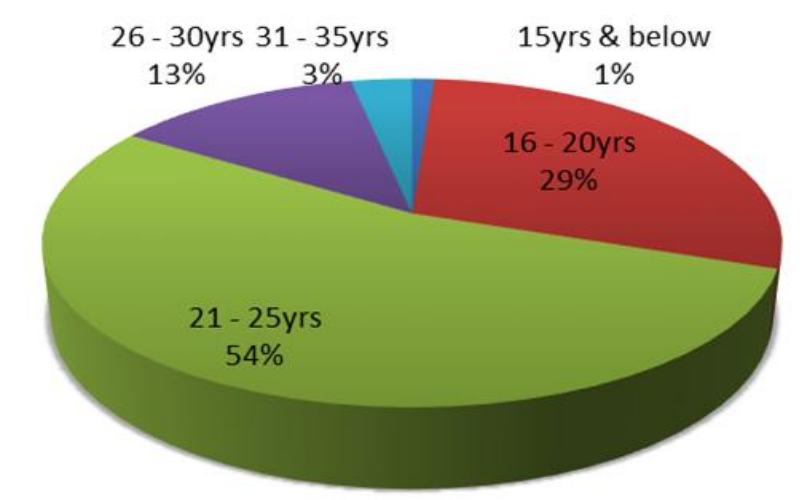

Figure 3 Age distribution of the respondents

Comment: $54 \%$ of Polytechnic students that have Instagram account fall within age group 21 - 25yrs while $29 \%$ fall within 16 - 20 age group finally, $1 \%$ of Polytechnic students fall within age 15 and below respectively.

Table 3Respondents' Polytechnics

\begin{tabular}{|l|l|l|}
\hline Polytechnic & Frequency & Percentage \\
\hline AdoPoly & 300 & 50.0 \\
\hline YabaTech & 300 & 50.0 \\
\hline Total & 600 & $100 \%$ \\
\hline
\end{tabular}

Table 3 shows Polytechnics the respondents are studying. It could be observed that $50 \%$ of the respondents are studying at The Federal Polytechnic, Ado Ekiti while 50\% of the respondents are studying at Yaba College of Technology, Lagos.

Table 4 Respondents' Faculties/Schools

\begin{tabular}{|l|l|l|}
\hline Schools & Frequency & Percentage \\
\hline SOS & 37 & 6.2 \\
\hline SMBS & 117 & 19.5 \\
\hline SSC & 113 & 18.8 \\
\hline SOE & 110 & 18.3 \\
\hline SES & 112 & 18.7 \\
\hline SADP & 37 & 6.2 \\
\hline SLS & 37 & 6.2 \\
\hline SOT & 37 & 6.2 \\
\hline Total & 600 & $100 \%$ \\
\hline
\end{tabular}

Table 4 presents the Schools of the respondents. The result reveals that $19.5 \%$ of the respondents are in the SMBS, $18.8 \%$ are in the SSC, $18.7 \%$ are in the SES, $18.3 \%$ are in the SOE while SOS, SADP, SLS and SOT have $6.2 \%$ respectively. It could be observed that majority of the respondents that have Instagram account are in the SMBS 


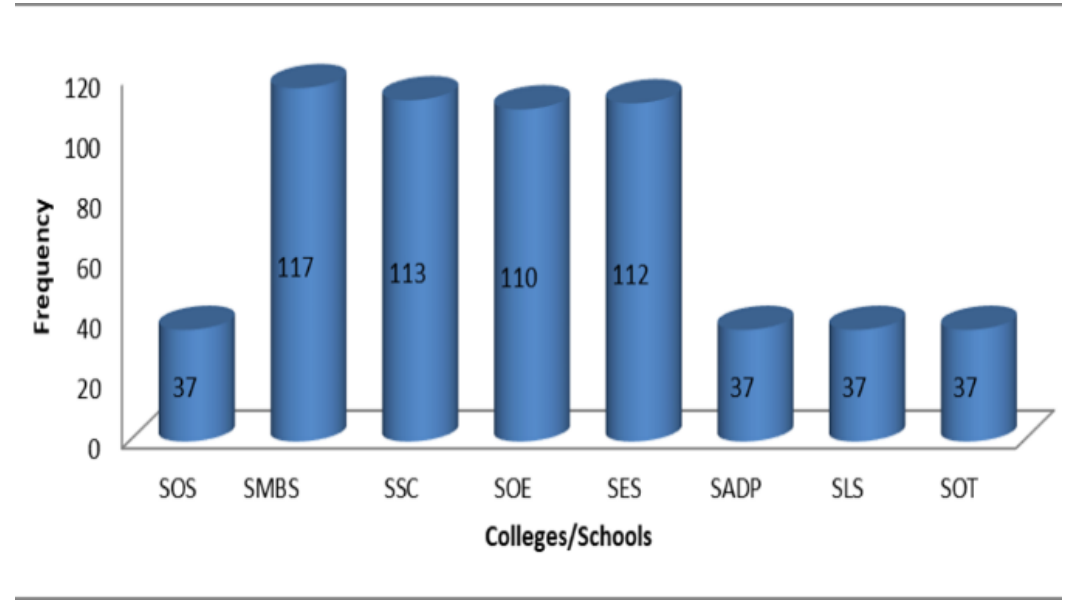

Figure 4 Distribution of respondents by different Colleges/Schools

\subsection{Research Question 1}

Are young Nigerian students conscious of their body image?

Table 5A Level of Consciousness of Nigerian students' body image

\begin{tabular}{|l|l|l|l|l|l|l|}
\hline Item & SA & A & SD & D & Mean & Std. Dev. \\
\hline I have a perfect body image & 330 & 217 & 11 & 42 & 1.61 & .834 \\
& $55 \%$ & $36.2 \%$ & $1.8 \%$ & $7 \%$ & & \\
\hline I have the urge to change my body size & 221 & 243 & 72 & 64 & 1.97 & .957 \\
& $36.8 \%$ & $40.5 \%$ & $12 \%$ & $10.7 \%$ & & \\
\hline I have the urge to change my complexion & 247 & 220 & 78 & 55 & 1.90 & .949 \\
& $41.2 \%$ & $36.7 \%$ & $13 \%$ & $9.2 \%$ & & \\
\hline I have the urge to change my body shape & 249 & 233 & 67 & 51 & 1.87 & .922 \\
& $41.5 \%$ & $38.8 \%$ & $11.2 \%$ & $8.5 \%$ & & \\
\hline I feel challenged with my body size & 217 & 235 & 81 & 67 & 2.00 & .972 \\
& $36.2 \%$ & $39.2 \%$ & $13.5 \%$ & $11.2 \%$ & & \\
\hline I feel uneasy with my complexion & 242 & 220 & 84 & 54 & 1.92 & .948 \\
\hline I feel uneasy with my body shape & $40.3 \%$ & $36.7 \%$ & $14 \%$ & $9 \%$ & & \\
& 259 & 218 & 77 & 46 & 1.85 & .920 \\
\hline I try to change my complexion & $43.2 \%$ & $36.3 \%$ & $12.8 \%$ & $7.7 \%$ & & \\
& 214 & 250 & 70 & 66 & 1.98 & .956 \\
\hline I try to control my weight & $35.7 \%$ & $41.7 \%$ & $11.7 \%$ & $11 \%$ & & \\
\hline I try to reshape my body & 226 & 290 & 39 & 45 & 1.84 & .847 \\
& $37.7 \%$ & $48.3 \%$ & $6.5 \%$ & $7.5 \%$ & & \\
\hline
\end{tabular}

Table 5 shows the level of consciousness of Nigerian students on their body image. The result reveals that $36.2 \%$ of the respondent agreed that they have a perfect body image, $55 \%$ strongly agreed that they have a perfect body image while $7 \%$ disagreed that they have a perfect body image while $1.8 \%$ strongly disagreed that they have a perfect body image (Mean=1.61, SD $=0.834$ ). Again, $40.5 \%$ of the respondents agreed that they have the urge to change their body sizes, $36.8 \%$ strongly agreed that they have the urge to change their body sizes, while $10.7 \%$ of the respondents disagreed that they have the urge to change their body sizes and $12 \%$ of the respondents strongly disagreed that they have the urge to change their body sizes (Mean $=1.97, \mathrm{SD}=0.957$ ). Furthermore, $38.8 \%$ of the respondents agreed that they have the urge to change their body shapes, $41.5 \%$ strongly agreed that they have the urge to change their body shapes while 
8.5\% disagreed that they have the urge to change their body shapes and $11.2 \%$ strongly disagreed that they have the urge to change their body shapes (Mean=1.87, $\mathrm{SD}=0.922$ ). Moreover, $36.3 \%$ of the respondents agreed that they felt uneasy with their body shapes, $43.2 \%$ strongly agreed that they felt uneasy with their body shapes while $7.7 \%$ disagreed that they felt uneasy with their body shapes and $12.8 \%$ strongly disagreed that they felt uneasy with their body shapes (Mean=1.85, SD=0.920). Finally, 37.5\% agreed that they tried to reshape their bodies, $42.2 \%$ strongly agreed that they tried to reshape their bodies while $10.5 \%$ disagreed that they tried to reshape their bodies and $9.8 \%$ strongly disagreed that they tried to reshape their bodies (Mean=1.89, SD=0.964). From the result, inference could be made that Nigerian students are conscious of their body image.

\subsection{Inferential Statistics (Chi Square Test)}

Table 5B Level of Consciousness of Nigerian students' body image

\begin{tabular}{|c|c|c|c|c|c|c|c|c|c|c|}
\hline \multirow[b]{2}{*}{$\begin{array}{l}\text { Consciousn } \\
\text { ess of Body } \\
\text { image }\end{array}$} & \multicolumn{10}{|c|}{ GENDER } \\
\hline & $\begin{array}{l}\text { I have } \\
\text { a } \\
\text { perfect } \\
\text { body } \\
\text { image }\end{array}$ & $\begin{array}{l}\text { I have } \\
\text { the } \\
\text { urge to } \\
\text { change } \\
\text { my } \\
\text { body } \\
\text { size }\end{array}$ & $\begin{array}{l}\text { I have the } \\
\text { urge to } \\
\text { change my } \\
\text { complexio } \\
n\end{array}$ & $\begin{array}{l}\text { I have the } \\
\text { urge to } \\
\text { change } \\
\text { my body } \\
\text { shape }\end{array}$ & $\begin{array}{l}\text { I feel } \\
\text { challen } \\
\text { ged } \\
\text { with my } \\
\text { body } \\
\text { size }\end{array}$ & $\begin{array}{l}\text { I feel } \\
\text { uneasy } \\
\text { with my } \\
\text { complexi } \\
\text { on }\end{array}$ & $\begin{array}{l}\text { I feel } \\
\text { uneas } \\
\text { y with } \\
\text { my } \\
\text { body } \\
\text { shape }\end{array}$ & $\begin{array}{l}\text { I try to } \\
\text { change } \\
\text { my } \\
\text { complexi } \\
\text { on }\end{array}$ & $\begin{array}{l}\text { I try to } \\
\text { control } \\
\text { my } \\
\text { weight }\end{array}$ & $\begin{array}{l}\text { I try to } \\
\text { reshap } \\
\text { e my } \\
\text { body }\end{array}$ \\
\hline$P$-value & 0.317 & 0.940 & 0.473 & 0.613 & 0.345 & 0.674 & 0.742 & 0.172 & 0.026 & 0.401 \\
\hline $\begin{array}{l}\text { Decision } \\
\text { Rule } \\
\text { ( } \alpha \text {-value= } \\
0.05)\end{array}$ & $\begin{array}{l}\mathrm{H}_{\mathrm{o}} \text { is } \\
\text { not } \\
\text { rejecte } \\
\mathrm{d}\end{array}$ & $\begin{array}{l}\mathrm{H}_{\mathrm{o}} \text { is } \\
\text { not } \\
\text { rejecte } \\
\mathrm{d}\end{array}$ & $\begin{array}{l}\mathrm{H}_{o} \text { is not } \\
\text { rejected }\end{array}$ & $\begin{array}{l}\mathrm{H}_{\mathrm{o}} \text { is not } \\
\text { rejected }\end{array}$ & $\begin{array}{l}\mathrm{H}_{\mathrm{o}} \text { is not } \\
\text { rejected }\end{array}$ & $\begin{array}{l}\mathrm{H}_{\mathrm{o}} \text { is not } \\
\text { rejected }\end{array}$ & $\begin{array}{l}\mathrm{H}_{\mathrm{o}} \text { is } \\
\text { not } \\
\text { reject } \\
\text { ed }\end{array}$ & $\begin{array}{l}\mathrm{H}_{\mathrm{o}} \text { is not } \\
\text { rejected }\end{array}$ & $\begin{array}{l}\mathrm{H}_{\mathrm{o}} \quad \text { is } \\
\text { rejected }\end{array}$ & $\begin{array}{l}\mathrm{H}_{\mathrm{o}} \text { is } \\
\text { not } \\
\text { rejecte } \\
\mathrm{d}\end{array}$ \\
\hline $\begin{array}{l}\text { Interpretati } \\
\text { on }\end{array}$ & $\begin{array}{l}\text { Studen } \\
\text { ts do } \\
\text { not } \\
\text { have } \\
\text { perfect } \\
\text { body } \\
\text { image }\end{array}$ & $\begin{array}{l}\text { Studen } \\
\text { ts do } \\
\text { not } \\
\text { have } \\
\text { urge to } \\
\text { change } \\
\text { their } \\
\text { body } \\
\text { size }\end{array}$ & $\begin{array}{l}\text { Students } \\
\text { do not } \\
\text { have urge } \\
\text { to change } \\
\text { their } \\
\text { complexio } \\
\text { n }\end{array}$ & $\begin{array}{l}\text { Students } \\
\text { do not } \\
\text { have urge } \\
\text { to change } \\
\text { their } \\
\text { body } \\
\text { shapes }\end{array}$ & $\begin{array}{l}\text { Student } \\
\text { s do not } \\
\text { feel } \\
\text { challen } \\
\text { ged } \\
\text { with } \\
\text { their } \\
\text { body } \\
\text { size }\end{array}$ & $\begin{array}{l}\text { Students } \\
\text { do not } \\
\text { feel } \\
\text { uneasy } \\
\text { with their } \\
\text { complexi } \\
\text { on }\end{array}$ & $\begin{array}{l}\text { Stude } \\
\text { nts do } \\
\text { not } \\
\text { feel } \\
\text { uneas } \\
\text { y with } \\
\text { their } \\
\text { body } \\
\text { shape }\end{array}$ & $\begin{array}{l}\text { Students } \\
\text { do not try } \\
\text { to change } \\
\text { their } \\
\text { complexi } \\
\text { on }\end{array}$ & $\begin{array}{l}\text { Students } \\
\text { try to } \\
\text { control } \\
\text { their } \\
\text { weights }\end{array}$ & $\begin{array}{l}\text { Studen } \\
\text { ts do } \\
\text { not try } \\
\text { to } \\
\text { reshap } \\
\text { e their } \\
\text { bodies }\end{array}$ \\
\hline
\end{tabular}

\subsection{Research Question 2}

What are the measures taken by young Nigerian students through Instagram posts to change their body features?

Table 6 shows measures taken by the students of two different Polytechnics in Nigeria to achieve their desired body image. The result reveals that $69.5 \%$ of the respondents used body whitening creams to achieve desired body image, while $30.5 \%$ didn't use body whitening creams to achieve desired body image (Mean=1.31, SD=0.461). Again, 75\% of the respondents used skin whitening treatments while $25 \%$ didn't use skin whitening treatments to achieve desired body image (Mean=1.25, SD=0.433). Furthermore, 65.5\% of the respondents engaged regular workout to achieve desired body image while $34.5 \%$ of the respondents didn't engage regular workout (Mean=1.35, SD=0.476). Finally, $72.7 \%$ of the respondents engaged fat burning program to achieve desired body image while $27.3 \%$ didn't engage fat burning program to achieve desired body image (Mean=1.27, $\mathrm{SD}=0.446$ ). From the result, inference could be made that Nigerian students actually employed most of these measures to achieve their desired body image. 
Table 6 Measures taken through Instagram posts to change body features

\begin{tabular}{|l|l|l|l|l|}
\hline Complexion & YES & NO & Mean & Std. Dev. \\
\hline Body Whitening Creams & 417 & 183 & 1.31 & .461 \\
& $69.5 \%$ & $30.5 \%$ & & \\
\hline Skin Whitening Treatments & 450 & 150 & 1.25 & .433 \\
& $75 \%$ & $25 \%$ & & \\
\hline Exfoliation & 441 & 159 & 1.27 & .442 \\
& $73.5 \%$ & $26.5 \%$ & & \\
\hline Bleaching & 467 & 133 & 1.22 & .416 \\
& $77.8 \%$ & $22.2 \%$ & & \\
\hline Body Whitening Pills & 449 & 151 & 1.25 & .434 \\
& $74.8 \%$ & $25.2 \%$ & & \\
\hline Slimming Pills & 365 & 235 & 1.39 & .489 \\
& $60.8 \%$ & $39.2 \%$ & & \\
\hline Slimming Tea & 306 & 294 & 1.49 & .500 \\
& $51 \%$ & $49 \%$ & & \\
\hline Regular Workout & 393 & 207 & 1.35 & .476 \\
& $65.5 \%$ & $34.5 \%$ & & \\
\hline Dieting & 365 & 235 & 1.39 & .489 \\
& $60.8 \%$ & $39.2 \%$ & & \\
\hline Fat Burning Program (Keto) & 436 & 164 & 1.27 & .446 \\
& $72.7 \%$ & $27.3 \%$ & & \\
\hline
\end{tabular}

\subsection{Research Question 3}

To what extent do young students patronize the products advertised on Instagram to acquire the ideal beauty standard?

Table 7 Extent of Patronized Body Image Products Advertised on Instagram?

\begin{tabular}{|l|l|l|l|l|l|}
\hline Item & Regular & Rarely & Never & Mean & Std. Dev. \\
\hline Body Whitening Creams & 369 & 70 & 161 & 1.65 & .874 \\
& $61.5 \%$ & $11.7 \%$ & $26.8 \%$ & & \\
\hline Skin Whitening Treatments & 379 & 64 & 157 & 1.63 & .870 \\
& $63.2 \%$ & $10.7 \%$ & $26.2 \%$ & & \\
\hline Skin Toning Soaps & 368 & 91 & 141 & 1.62 & .840 \\
& $61.3 \%$ & $15.2 \%$ & $23.5 \%$ & & \\
\hline Body Whitening Pills & 366 & 62 & 172 & 1.68 & .891 \\
& $61 \%$ & $10.3 \%$ & $28.7 \%$ & & \\
\hline Exfoliation Scrubs & 359 & 102 & 139 & 1.63 & .835 \\
& $59.8 \%$ & $17 \%$ & $23.2 \%$ & & \\
\hline Flat Tummy Products & 377 & 78 & 145 & 1.61 & .850 \\
& $62.8 \%$ & $13 \%$ & $24.2 \%$ & & \\
\hline Slimming Pills & 389 & 56 & 155 & 1.61 & .869 \\
& $64.8 \%$ & $9.3 \%$ & $25.8 \%$ & & \\
\hline Weight Loss Products & 398 & 73 & 129 & 1.55 & .824 \\
& $66.3 \%$ & $12.2 \%$ & $21.5 \%$ & & \\
\hline Slimming Tea & 386 & 77 & 137 & 1.59 & .837 \\
& $64.3 \%$ & $12.8 \%$ & $22.8 \%$ & & \\
\hline Body Shaping Diet Pills & 399 & 75 & 126 & 1.55 & .818 \\
& $66.5 \%$ & $12.5 \%$ & $21 \%$ & & \\
\hline
\end{tabular}


Table 7 shows the extent of patronized Body Image Products Advertised on Instagram by students of two different Polytechnics in Nigeria. The result reveals that $61.5 \%$ of the respondents agreed that they regularly patronize body whitening creams advertised on Instagram, $11.7 \%$ said they rarely patronize body whitening creams advertised on Instagram while $26.8 \%$ said they never patronize body whitening creams advertised on Instagram (Mean=1.65, $\mathrm{SD}=0.874$ ). Again, $61.3 \%$ of the respondents agreed that they regularly patronize skin toning soaps advertised on Instagram, $15.2 \%$ said they rarely patronize skin toning soaps advertised on Instagram while $23.5 \%$ said they never patronize skin toning soaps advertised on Instagram (Mean=1.62, SD=0.840). More so, 64.8\% of the respondents agreed that they regularly patronize slimming pills advertised on Instagram, 9.3\% said they rarely patronize slimming pills advertised on Instagram while $25.8 \%$ said they never patronize slimming pills advertised on Instagram (Mean=1.61, $\mathrm{SD}=0.869$ ). In the same vein, $64.3 \%$ of the respondents agreed that they regularly patronize slimming tea advertised on Instagram, $12.8 \%$ said they rarely patronize slimming teas advertised on Instagram while $22.8 \%$ said they never patronize slimming teas advertised on Instagram (Mean=1.59, SD=0.837). Finally, $66.5 \%$ of the respondents agreed that they regularly patronize body shaping diet pills advertised on Instagram, $12.5 \%$ said they rarely patronize body shaping diet pills advertised on Instagram while $21 \%$ said they never patronize body shaping diet pills advertised on Instagram (Mean=1.55, SD=0.818). From the result, inference could be made that students really patronize body image products advertised on Instagram to acquire their ideal beauty standard.

\subsection{Research Question 4}

What are the psychological effects that Instagram posts on body image have on Nigerian undergraduates?

Table 8 Level of Psychological Effects that Instagram posts have on body image

\begin{tabular}{|l|l|l|l|l|l|}
\hline Item & Highly & Minimal & Low & Mean. & Std. Dev. \\
\hline I derive inspiration through Instagram Posts & 297 & 233 & 70 & 1.62 & .685 \\
& $49.5 \%$ & $38.8 \%$ & $11.7 \%$ & & \\
\hline I derive inspiration through Instagram Models & 251 & 215 & 134 & 1.81 & .778 \\
& $41.8 \%$ & $35.8 \%$ & $22.3 \%$ & & \\
\hline I receive encouragement through & 256 & 246 & 98 & 1.74 & .722 \\
Instagram models & $42.7 \%$ & $41 \%$ & $16.3 \%$ & & \\
\hline I receive encouragement through & 236 & 279 & 85 & 1.75 & .687 \\
Instagram posts. & $39.3 \%$ & $46.5 \%$ & $14.2 \%$ & & \\
\hline I derive confidence through Instagram Posts & 293 & 207 & 100 & 1.68 & .743 \\
& $48.8 \%$ & $34.5 \%$ & $16.7 \%$ & & \\
\hline I derive confidence through Instagram & 218 & 246 & 136 & 1.86 & .756 \\
Celebrities. & $36.3 \%$ & $41 \%$ & $22.7 \%$ & & \\
\hline I build my self-esteem through & 224 & 257 & 119 & 1.83 & .736 \\
Instagram posts. & $37.3 \%$ & $42.8 \%$ & $19.8 \%$ & & \\
\hline I build self-esteem through Instagram & 185 & 259 & 156 & 1.95 & .753 \\
Models & $30.8 \%$ & $43.2 \%$ & $26 \%$ & & \\
\hline I desire to have the look of & 223 & 242 & 135 & 1.85 & .759 \\
Instagram models. & $37.2 \%$ & $40.3 \%$ & $22.5 \%$ & & \\
\hline I feel oppressed with the body of & 201 & 214 & 185 & 1.97 & .802 \\
Instagram models & $33.5 \%$ & $35.7 \%$ & $30.8 \%$ & & \\
\hline
\end{tabular}

Table 8 shows results on level of Psychological Effects that Instagram posts have on body image. It could be observed that $49.5 \%$ of the respondents agreed that the level of inspiration they derived through Instagram posts on their body image is high while $11.7 \%$ of the respondents believed it is low (Mean=1.62, SD=0.685). Again, $42.7 \%$ of the respondents agreed that the level of encouragement they received through Instagram posts on their body image is high while $16.3 \%$ of the respondents believed it is low (Mean=1.74, SD=0.722). Also, 48.8\% of the respondents agreed that the level of confidence they derived through Instagram posts on their body image is high while $16.7 \%$ of the respondents believed it is low (Mean=1.68, SD=0.743). In the same vein, 37.3\% of the respondents agreed that the level of self-esteem they built through Instagram posts on their body image is high while $19.8 \%$ of the respondents believed it is low (Mean=1.83, 
$\mathrm{SD}=0.736)$. Finally, $33.5 \%$ of the respondents agreed that the level of oppression they felt through Instagram posts on their body image is high while $30.8 \%$ of the respondents believed it is low (Mean=1.97, SD=0.802). From the result, inference could be made that the level of Psychological Effects that Instagram posts have on body image is high (88\%)

\section{Conclusion}

Based on the result of analysis carried out on this study, It can be concluded that Nigerian students are highly conscious of their body image, they employed different measures to achieve their desired body image, the rate at which Nigerian students patronize product advertised on Instagram to acquire ideal beauty standard is high and level of psychological effect of Instagram posts on body image is high (88\%).

\section{Compliance with ethical standards}

\section{Acknowledgments}

This work is funded mainly by TETFUND, Nigeria.

\section{Disclosure of conflict of interest}

The authors declare that they have no conflicts of interests.

\section{Statement of informed consent}

Informed consent was obtained from all individual participants included in the study."

\section{References}

[1] Abbott, W., Donaghey, J., Hare, J. and Hopkins, P. An Instagram is Worth a Thousand Words: An Industry Panel and Audience Q\&A. Library Hi Tech News. 2013; 30(7): 1-6.

[2] Adamic, L., and Adar, E. How to Search a Social Network. Social Network. 2005; 27(3): 187-203.

[3] Agliata, D., Tantleff-Dunn, S. The Impact of Media Exposure on Males Body Image. Journal of Social and Clinical Psychology. 2004; 23(1): 7-22.

[4] Bakhshi, S., Shamma, D. A. and Gilbert, E. Faces Engage Us: Photos with Faces Attract More Likes and Comments on Instagram. 2013.

[5] Barlett, C. P., Vowels, C. L. and Saucier, D. A. Meta-Analyses of the Effects of Media Images on Men Body-image Concerns. Journal of Social and Clinical Psychology. 2013; 27(3): 279-310.

[6] Bergstrom, T. and Backman, L. Marketing and PR in Social Media: How the utilization of Instagram builds and maintains customer relationship. Media and Communication. 2013.

[7] Boyd, D. M. and Ellison, N. B. Social network sites: definition, history, and scholarship, Journal of ComputerMediated Communication. 2007; 13(1): 210-230.

[8] Campbell, D. Body image concerns more men than women, research finds. Retrieved. 12 June 2017.

[9] Constine, J. Instagram's growth speeds up as it hits 700 million users. Retrieved14 June 2017.

[10] Chante, K., Jessica, C., Lindsay, B., Tyler, Q. and Robert, P. D. Dermatology on Instagram. Dermatology Online Journal. 2014; 20(7): 1-6.

[11] Grabe, S., Ward, L. M. and Hyde, J. S. The Role of the Media in Body Image Concerns Among Women: A Meta-Analysis of Experimental and Correlational Studies. Psychological Bulletin. 2008; 134(3): 460-476.

[12] Hochman, N. and Schwartz, R. Visualizing Instagram: Tracing Cultural Visual Rhythms. In the proceedings of the workshop on Social Media Visualization in Conjunction with the 6th International AAAI Conference on Weblogs and Social Media. 2012.

[13] Li, Z. and Agarwal, A. Impact of Platform Owner's Entry into Complementary Market on Consumer Demand: Evidence from Facebook's Acquisition of Instagram. 2014. 
[14] Olofin, N. G., Babaleye, S. O. T. and Adamolekun, W. Image Promotion on Instagram by Female Students in some Nigerian Universities. Advances in Social Sciences Research Journal. 2020; 7(11).

[15] Robertson, V. The "Normal Barbie:" Setting the Ideal Female Body Image Right. 2014.

[16] Salomon, D. (2013). Moving on from Facebook: Using Instagram to connect with Undergraduates and engage in teaching and learning. ACRL Tech Connect, 408-412

[17] Smith, C. By the Numbers: 85 interesting Instagram Statistics. Digital Marketing Ramblings. 2014.

[18] Wagner, C., Aguirre, E. and Sumner, E. M. The Relationship between Instagram Selfies and Body Image in Young Adult Women. 2016; 21(9).

[19] Yamamiya, Y. Cash, T. F., Melnyk, S. E., Posavac, H. D. and Posavac, S. S. Women Exposure to Thin-and-Beautiful Media Images: Body Image Effects of Media-Ideal Internalization and Impact-Reduction Interventions. Body Image. 2005; 2(1): 74-80.

[20] Yayli, A., Bayram, M. and Bayram, Ü. How Social Media Works in Destination Marketing? A Content Analysis on Twitter. Retrieved on 11 August 2014. 